\title{
A review of four decades of research in organisational career psychology by academia in South Africa
}

\author{
Authors: \\ Dries Schreuder ${ }^{1}$ \\ Melinde Coetzee ${ }^{1}$ \\ Affiliations: \\ ${ }^{1}$ Department of Industrial \\ and Organisational \\ Psychology, University of \\ South Africa, South Africa \\ Correspondence to: \\ Dries Schreuder \\ Email: \\ schreamg@unisa.ac.za \\ Postal address: \\ PO Box 392, University of \\ South Africa, Pretoria 0003 , \\ South Africa \\ Dates: \\ Received: 10 Apr. 2012 \\ Accepted: 18 Sept. 2012 \\ Published: 03 Dec. 2012 \\ How to cite this article: \\ Schreuder, D., \& Coetzee, \\ M. (2012). A review of \\ four decades of research \\ in organisational career \\ psychology by academia \\ in South Africa. SA Journal \\ of Human Resource \\ Management/SA Tydskrif vir \\ Menslikehulpbronbestuur, \\ 10(2), Art. \#474, 10 pages. \\ http://dx.doi.org/10.4102/ \\ sajhrm.v10i2.474
}

C) 2012. The Authors. Licensee: AOSIS OpenJournals. This work is licensed under the Creative Commons Attribution License.
Orientation: Career research in organisations has increased in importance since the 1970s, which heralded new directions for organisational career research and practice both globally and nationally.

Research purpose: The study critically reviewed trends in organisational career psychology research in South Africa from 1970 to 2011 in terms of global and present national challenges that require empirical investigation in the contemporary South African world of work context.

Motivation for the study: The increasingly complex contexts, in which people have been pursuing their careers since the catalytic 1970s, demand the continuous generation and development of knowledge for the benefit of the discipline and practice of careers.

Research design, approach and method: A broad systematic review was carried out to analyse documented academia research $(N=110)$ on careers from 1970 to 2011, which was published in six accredited South African scientific journals.

Main findings: Much of the research addressed issues pertaining to career theory and concepts, the world of work and career assessment and technology. Career development, professional issues and organisational career interventions in the multi-cultural South African context appear to be under-researched.

Practical/managerial implications: The insight derived from the findings can be employed by academia and researchers, in this field, to plan future research initiatives that will contribute to the profession and practice of career guidance and counselling in the contemporary workplace.

Contribution/value-add: The findings provide preliminary insight that adds to the body of knowledge concerned with career studies in the South African organisational context.

\section{Introduction \\ Key focus of the study}

Career research '... will have to match the nature of its subject: rapidly changing, fast learning and complex' (Hall \& Mirvis, 1995, p. 349).

Career research in organisations has increased in importance since the 1970s, a period which heralded new directions for career research both globally and nationally. Representing the renewal of the careers field, the 1970s witnessed a reinvention and regeneration of innovative theory production, collegial dialogue and the establishment of the careers field in professional societies (Derr \& Briscoe, 2007). This was achieved under the mentoring influence of Edgar Schein of the Sloan School of Management at the Massachusetts Institute of Technology (MIT). Today it is recognised that the increasingly complex and turbulent contexts in which people have been pursuing their careers, since the catalytic 1970s, continue to demand the generation and development of knowledge for the benefit of the discipline and practice of careers (Creager, 2011; Krieshok, Motl \& Rutt, 2011; Obschonka, Silbereisen \& Wasilewski, 2012; Savickas, 2011). Derr and Briscoe (2007) also regard career research as a central element of contemporary organisational studies.

\section{Background to the study}

Career psychology was legitimised as a field within the more generalised field of organisation studies during the mid-1970s. During the mid-1980s and early 1990s, the emergence of the socalled knowledge economy resulted in scholars drastically rethinking the very nature of work and careers (Gunz \& Peiperl, 2007). Globalisation, technological advances, changes in industrial and employment structures for production flexibility, political change and the diversification of workforce demographics (within a context of heightened economic uncertainty and turbulence) witnessed the emergence of the boundary-less and so-called 'non-traditional' career in the late 
1990s and early 2000s (Gunz \& Peiperl, 2007; Obschonka et al., 2012; Savickas, 2011).

Since the early 2000s, there has been a continuance of these trends along with rising unemployment and concerns about skills scarcity, which increasingly affect the jobs, careers and lives of people in the 21st century (Schreuder \& Coetzee, 2011). Savickas (2011) emphasises the need for the information societies of the 21st century to learn how to deal with uncertainty, numerous employment transitions and jobless or temporary work assignments. Savickas posits that career studies, whilst adopting a constructionist research paradigm, should focus attention on peoples' employability rather than on their employment (2011). Innovative career counselling and development theories and practices are required, that help individuals develop the required career adaptability skills to reconceptualise their careers in the 21st century and redesign their working lives. Obschonka et al. (2012) further point to a lack of research on individuals' subjective experiences (intraindividual constellations) of change-related demands. Schein (2007) emphasises that career research in the 21st century world of work should continue to address contemporary problems faced by individuals and organisations. Apart from contributing new, relevant knowledge and innovative solutions to the career challenges of the contemporary world of work (Savickas, 2011), career scholars (and their research) need to help management scholars and practitioners recognise the primacy of career theory and scholarship to the key questions facing organisations and individuals today (Derr \& Briscoe, 2007).

\section{Research objective}

Given the importance of career research in the contemporary world of work context, the purpose of this study was to explore organisational career research trends by academia in South Africa from 1970 to 2011. Its purpose was also to evaluate these trends in terms of global and present national challenges that require empirical investigation in the contemporary, multi-cultural South African world of work context.

The research questions were as follows:

- What core research themes emerge from career research in organisations by academia in South Africa from 1970 to 2011 ?

- What are the implications of these research themes with regard to global and present national challenges that require empirical investigation in the contemporary, multi-cultural South African world of work context?

\section{Potential value-add of the study}

The increasingly complex contexts in which people have been pursuing their careers since the catalytic 1970s demand the continuous generation and development of knowledge for the benefit of the discipline and practice of careers. Apart from the global changes that affect the nature of work and careers, the post-apartheid context of South African workplaces also poses unique career-related challenges to individuals and professional career counsellors.

The insights derived from the findings may be employed by academia and researchers when planning future research initiatives. Given the paucity of empirical work on career research trends in South Africa, the findings may provide preliminary insights that add to the body of knowledge concerned with the evolution of the field and professional practice in the South African context.

\section{Literature review}

According to Derr and Briscoe (2007), the concepts of career and career success (Hall, 1976) and the internal career orientations of people (Driver, 1980; Schein, 1977, 1996, 2006) were major themes in the international careers literature from the 1970s onwards. Information about adult life stage development (Levinson, 1978; Super, 1990) and the importance of work-life balance (Bailyn, 1977, 1980) grew in intensity. In America, women's rights in the workplace, careers and affirmative action became popular themes in the 1970s and are even more so today (Derr \& Briscoe, 2007). The social context of careers and its boundary-less nature increasingly received attention (Arthur, Inkson \& Pringle, 1999). Research on careers and organisations focused on planning, staffing, socialisation and mentoring as well as job enrichment issues (Derr \& Briscoe, 2007).

In the 21st century, career research in organisations increasingly started to focus on succession planning, attracting, managing and retaining talent and high-potential employees (Conger \& Fulmer, 2003; Derr \& Briscoe, 2007; Derr, Briscoe \& Buckner, 2002). Chaichanasakul et al. (2011) analysed 830 articles that were published in the Journal of Career Development from 1972 to 2007. They concluded that articles related to the theme 'career counselling and interventions' had been published most frequently in this journal. They further established that the five most frequently studied variables were the following:

1. career guidance (mostly published prior to 1990, coinciding with the vocational guidance movement originated by Frank Parsons in the 1970s and 1980s)

2. career programming and interventions

3. cross-cultural issues (including constructs such as women's career issues, cross-national studies, career issues amongst racial and ethnic minorities, and social class-related career issues)

4. career counselling process and outcome

5. career aspirations.

Articles related to career assessment (scale development and validation of career-related measurements) and career issues at work (career commitment, networking, management, and career transition) were amongst the least often studied.

In an extensive 2010 review of both quantitative and qualitative career development and counselling research 
published in international scientific journals, Creager (2011) highlighted the following as dominant themes in career research literature:

- Research on issues of professional importance: Studies highlighted the need for continued training in multicultural awareness and skills, including counsellor burnout, values and their work lives. The multicultural competence of professional career development counsellors includes an awareness of the diverse needs of employees from historically disadvantaged populations, people with disabilities, those who are economically deprived, unemployed, underemployed and culturally different from other worker populations. Other research themes include social justice and advocacy in terms of the availability and provision of supportive career development systems and options for all populations in the workplace (Creager, 2011).

- Research on career theory and concepts: Research studies mostly revised or expanded on existing theory, providing additional empirical support for a theory or a construct. As was also established in the review by Chaichanasakul et al. (2011), these studies mostly focused on Holland's theory of career personality and work (50th anniversary), Social Cognitive Career Theory (SCCT) and the utility of the constructs of self-efficacy and interests as predictors of career goals and choices. Research that examined developmental theories mostly used student populations and focused on constructs such as cognitive development, career maturity, career exploration, career decisionmaking, career adaptability and career calling. Other constructs included factors related to career indecision, such as career self-efficacy, career-related emotional maturity, information needs, vocational identity development, the career decision status of students, individual background variables (e.g. gender, family, peers, income status, beliefs), and psychological and social cognitive factors (Creager, 2011).

- Developmental life stage studies: Research has indicated a need for childhood developmental models of career development relating to career choice and attainment. Research studies that examined young people aged 11-19 years (middle childhood and adolescence) focused on gender-related differences relating to early interests, influences on academic and career development, future time perspective and career planning, career aspirations, decision making and goals as well as school engagement. Research on populations in the school-to-work transition phase (young adulthood) identified the following themes as important factors in career and life planning: social support and relationships, expectations of adversity and adaptability, optimism regarding future opportunities, the evolution of work values and career identity, job instability and personality traits, work adjustment and the influence of gender-family roles on work value-work reward discrepancy and job satisfaction. Studies of midlife and older adults focused on the moderating effect of job complexity and age on opportunities (Creager, 2011). Chaichanasakul et al. (2011) established in their review that Super's Life Span/Development theories mostly drove research on developmental life stage studies.
- Research on the world of work: Studies focused on career dynamics in the workplace and the concept of the boundary-less career, employees' perceptions of career success, work and job satisfaction, work burnout, unemployment, work-related change, work-family interface and flexible work arrangements, mentoring, career mobility and work engagement. Some studies examined the workplace for lesbian and gay people, and the relationship between organisational heterosexism, citizenship behaviour and performance. Other themes focused on the Big Five personality traits and their relationship to various work-related constructs. The career decision processes of employed adults, career adjustment to change and workers coping with an uncertain and changing work situation were also examined. The role of work embeddedness in mediating the influence of negative events causing thoughts of leaving a job between job performance and organisational citizenship behaviours was also investigated. Some studies emphasised a vocational self-concept as an important aspect of career self-management in optimising current person-job fit. Other studies focused on cohort differences relating to work (e.g. the perceived career needs of millennials and employees in the early adulthood phase of their careers) (Creager, 2011).

- Research on career assessment and technology: Career assessment research included studies on the development of new measures, revision or refinement of instruments, evaluation of measures and career interest assessment. Core themes in career assessment research were career decision making or indecision, self-efficacy, family influence, goal mastery, sexual identity management, personality, working alliance and childhood career development. Career assessment technology research focused on the use of the Internet or web-based assessment systems and online virtual career counselling centres for career choice and development (Creager, 2011).

- Research on career interventions: Studies on career interventions mostly focused on career courses and mentoring activities in the school and post-school environment. Constructivist career courses were emphasised, focusing on planning skills, personal meaning-making and the co-creation of knowledge resulting in empowering career behaviour. Self-efficacy interventions were also a major research theme (Creager, 2011).

Since the mid-2000s, international organisational career research increasingly started to focus on the post-modern approaches to career counselling, such as life-career design (Hartung, 2011; Savickas, 2009) and Savickas's (2005) and Savickas's et al. (2009) career construction theory. The role of emotions in careers has also become an increasingly important theme (Brown, George-Curran \& Smith, 2003; Hartung, 2011). Themes, such as the following, are growing in importance:

- career and subjective well-being (Cotter \& Fouad, 2011; Kidd, 2008)

- employability (Fugate, Kinicki \& Ashforth, 2004; Van der Heijde \& Van der Heijden, 2006) 
- job and career embeddedness (Feldman \& Ng, 2007)

- job and career mobility ( $\mathrm{Ng}$, Sorensen, Eby \& Feldman, 2007)

- work-life enrichment (Greenhaus \& Powell, 2006).

These themes reflect the changing nature of the world of work and careers, which requires people to develop their career meta-competencies or psychological career resources that they require to design a meaningful life-career in an uncertain, more chaotic world of work (Schreuder \& Coetzee, 2011).

Research in organisational career psychology in South Africa did not receive much attention from researchers in the early years between 1950 and 1970. According to a study by Schreuder and Coetzee (2010), covering the period from 1950 to 1979, only 10 scientific career-related research projects were published; between 1980 and 2008 there was a significant increase in career research and 233 articles were published in scientific journals. These figures include peerreviewed articles, and master's and doctoral dissertations. In the broader context, this represents only $10 \%$ of the total number of publications in industrial and organisational psychology from 1950 to 2008. Table 1 provides an overview of the core career-related research themes identified by the study of Schreuder and Coetzee (2010).

\section{Present challenges for career research in South Africa}

Apart from the global challenges posed to the career development of people in the 21st century, individuals pursuing careers in the post-apartheid South African multicultural work context, face the reality of dealing with issues and challenges relating specifically to affirmative action and employment equity policies. These policies provide greater career and job mobility opportunities to Black people and women in particular. Research on attracting, developing and retaining talented and scarce or critical skills staff from the equity pool will remain a concern for South African organisations in the foreseeable future (Coetzee, 2011). South Africa is an understudied population, and new knowledge and insights are required on the career experiences and needs of Black women and people with disabilities in particular.

The relationship between career development and socioeconomic and educational background, race or ethnicity, and gender needs attention, as a result of the crucial place this relationship occupies in optimal career development (Creager, 2011). Moreover, the prevalence of HIV and AIDS in South African workplaces and communities (DHET, 2010) needs continued research, focusing on how these affect the career development of people, their well-being and success. In addition, the following need to be facilitated by research initiatives:

- youth employment

- graduate employability

- vocational guidance and skills development and induction to work as a vital bridge into productive and satisfying adulthood.
TABLE 1: Overview of South African career research themes in organisations from 1950 to 2008 .

\begin{tabular}{|c|c|}
\hline Time period & Dominant themes \\
\hline 1950-1959 & - Personality and occupational adjustment \\
\hline 1960-1969 & $\begin{array}{l}\text { - Retirement planning } \\
\text { - Vocational guidance } \\
\text { - Role conflict (career women) }\end{array}$ \\
\hline 1970-1979 & $\begin{array}{l}\text { - Career stages } \\
\text { - Occupational choices of women } \\
\text { - Career counselling of Black people } \\
\text { - Career mobility of Black people and graduates }\end{array}$ \\
\hline 1980-1989 & $\begin{array}{l}\text { - Career planning and development } \\
\text { - Career advancement } \\
\text { - Mid-career transition } \\
\text { - Quality of work life } \\
\text { - Organisational choice and personality } \\
\text { - Occupational concerns, needs and aspirations of women } \\
\text { - Cork-home interface } \\
\text { - Leadership styles } \\
\text { - Promotion of Black managers } \\
\text { - Black advancement } \\
\text { - Person-job match } \\
\text { - Self-concept (Black executives) } \\
\text { - Time orientation, psychological depth orientation and } \\
\text { occupational choice }\end{array}$ \\
\hline 1990-1999 & $\begin{array}{l}\text { - Mentorship and coaching (women) } \\
\text { - Job hunting skills (graduates) } \\
\text { - Career exploration } \\
\text { - Career self-management } \\
\text { - Job insecurity } \\
\text { - Personality and careers } \\
\text { - Career resilience } \\
\text { - Career patterns and career orientations \& personality } \\
\text { - Career maturity } \\
\text { - Career expectations } \\
\text { - Career salience } \\
\text { - Career adjustment } \\
\text { - Meaning of work } \\
\text { - Eualifications and career success } \\
\text { - Employability of graduates } \\
\text { - Job loss and outplacement } \\
\text { - Learning styles and occupational choice }\end{array}$ \\
\hline $2000-2008$ & $\begin{array}{l}\text { - Psychological career resources } \\
\text { - Employability } \\
\text { - Career orientations } \\
\text { - Work-home interface } \\
\text { - Work-life balance } \\
\text { - Job insecurity } \\
\text { - Career maturity } \\
\text { - Career success and satisfaction } \\
\text { - Career advancement } \\
\text { - Career development } \\
\text { - Job loss } \\
\text { - Working women } \\
\text { - Work experiences of gay people } \\
\text { - Personality and career preferences }\end{array}$ \\
\hline
\end{tabular}

Source: Schreuder, A.M.G., \& Coetzee, M. (2010). An overview of industrial and organisational psychology research in South Africa: A preliminary study. SA Journal of Industrial Psychology/SA Tydskrif vir Bedryfsielkunde, 36(1), Art. \#903, 11 pages. http:// Industrial Psychology/SA Tydskrif vir

The unemployed South African youth also remain an area of great concern (DHET, 2010). Research by Crocetti, Palmonari and Pojaghi (2011) emphasises the importance of understanding the career development needs and life outlook of the emerging adult (young people aged between 18 and 28). They found that emerging adults (Arnett, 2000) who face the challenge of finding their own occupation earlier, or with a lower level of education, experienced less satisfaction in life and had a less positive future orientation than their peers with a higher educational level. They also appear to feel less equipped, than their peers, to deal with continuous changes in a labour market that increasingly requires highly specialised workers. These findings suggest the need for further empirical research in the South African work context.

The changing nature of work and careers in a multi-cultural and multi-generational work context has, for many people, 
made some motivational and career development theories less relevant. This, in turn, calls for new, more relevant theories and measures to encourage greater career agency and career self-management (Bergh, 2009). Creager (2011) advocates the need for research on culturally sensitive approaches to career counselling and assessment.

\section{What will follow}

In the next section, the research design for this paper will be elaborated on and the research approach and method will be covered. The results will then be presented and the findings discussed. The article concludes with a brief synopsis of the most important conclusions, limitations of the research design and recommendations for possible future research initiatives.

\section{Research design \\ Research approach}

A broad qualitative systematic review (Petticrew \& Roberts, 2006) was undertaken. This approach allowed the researchers to gather, analyse, report and evaluate documented research evidence on organisational career psychology in terms of its relevance for inclusion in the database, and to categorise the data in terms of the dominant career psychology research sub-themes.

\section{Research method}

\section{Research setting}

In the context of the present study, the field of organisational career psychology was targeted to achieve the aim of the present study. The study was anchored in the academic domain and focused on documented research in the field of organisational career psychology in South Africa.

\section{Researcher roles}

As a result of the qualitative nature of the research, the researchers acted as the research tool. In an effort to ensure objectivity in the data analyses, the researchers remained constantly aware of their personal views and potential bias, and how such subjectivity might influence the objectivity and neutrality of the research findings.

\section{Sources of data}

As a result of being anchored in the academic domain, the boundary of the systematic review was defined to include only documented research in the field of organisational career psychology in South Africa. This included 110 published articles on career research from 1970 to 2011 from the following six peer-reviewed Department of Higher Education and Training-accredited South African scientific journals:

- South African Journal of Industrial Psychology

- South African Journal of Human Resource Management

- South African Journal of Psychology

- Acta Academica
- South African Journal of Labour Relations

- Southern Africa Business Review.

The 110 research articles were treated as the sources of data and the identified themes were treated as the data.

\section{Data collection methods}

A search was undertaken by means of an on-line information technology service, the South African Bibliographic Information Network (SABINET). Using 'career' as the keyword and within the context of the stated boundary of the research, the data included studies $(N=110)$ carried out during the past 40 years in organisational career psychology. The searches were conducted over a period of 12 months.

\section{Recording of data}

Databases were systematically reviewed and synthesised, using a pre-established categorisation framework (Creager, 2011; Esterberg, 2002; Petticrew \& Roberts, 2006). Codes and labels were attached to emerging themes that fit in the categorisation framework. All data were retained for possible future scrutiny. The data were safely stored to protect them from loss, destruction and unauthorised access.

\section{Data analyses}

In line with an international study conducted by Creager (2011), a categorisation framework was established a priori. Given this, the following six sub-themes of career psychology formed the basis for the categorisation framework used to synthesise the data:

- research on issues of professional importance

- research on career theory and concepts

- developmental life stages studies

- research on the world of work

- research on career assessment and technology

- research on organisational career interventions.

In line with recommendations from Esterberg (2002), the focused categorisation process entailed manually going through the sources of data, line by line, to identify the dominant themes and focusing on the key categories identified for the purposes of this research.

\section{Strategies employed to ensure quality data}

The objectivity and trustworthiness, of the data analysis process, were maximised by involving two researchers who were both experienced in systematic data analysis, making sure that they discussed their own possible biases throughout and continually looking for evidence that either contradicted or confirmed the themes. The average agreement rate was $98 \%$ (i.e. $98 \%$ of the factors were allocated to the same theme categories by each researcher). As a form of researcher triangulation, comments from researchers on the evolution of and challenges in the career psychology field (Creager, 2011; Derr \& Briscoe, 2007; Gunz \& Peiperl, 2007; Krieshok et al., 2011; Obschonka et al., 2012; Savickas, 2011) were also considered in the interpretation of the findings. 


\section{Reporting}

The results of the systematic review are presented in terms of the chosen categorisation framework. Descriptive statistics (\% frequencies and core themes) are used to present the dominant research trends.

\section{Findings}

Table 2 provides an overview of general (South African) research in the careers field frequency trends from 1970 to 2011, within the six pre-determined research theme categories. The sub-themes identified for each of the six research themes emerged from a scientifically rigorous analysis of the 110 research articles that were published from 1970 to 2011, in the six South African scientific journals listed above. Due to the extent of the number of publications in each of these journals, only the themes and the sub-themes are reported here, without reference to specific sources and examples for the sake of scientific parsimony. All data were retained for possible future scrutiny. This approach is in agreement with the research approach followed by Schreuder and Coetzee (2010) to report findings of this nature and extent.

\section{Theme 1: Issues of professional importance}

Table 2 shows that research on themes in this category represented proportionally $7.3 \%(n=8)$ of all the theme categories of the published articles. Core themes relating to issues of professional importance included: career counselling, career planning practices, career guidance system, and the profile of the industrial psychologist.

\section{Theme 2: Career theory and concepts}

Studies on career theory and concepts represented proportionally $27.3 \%(n=30)$ of all the theme categories of the published articles. Core themes included: career theories, career identity, career salience, career resilience, career patterns, career anchors or orientations, career attitudes, career choice, career success, career aspirations, career advancement, psychological career resources, vocational interest, and personality traits.

\section{Theme 3: Developmental life stage studies}

Research on themes in this category represented proportionally $10.9 \%(n=12)$ of all the theme categories of the published articles. Core themes included: life stage perspectives, career development, career decision or indecision, career maturity, early career, career expectations, and barriers to career advancement.

\section{Theme 4: World of work}

Table 2 shows that themes in the world of work category $(n=29 ; f=26.4 \%)$ proportionally dominated career research by academia in South Africa. The dominant themes in this category included: developing women's potential, working women, graduate women's job expectations, psychological contract, job satisfaction, career and life balance, work and family conflict, retention, work readiness, protean career, boundary-less career, work and family interface and spillover and enrichment, internal career, work-related concerns of HIV and AIDS, burnout, retention factors, job embeddedness, career mobility, work engagement, and subjective work experiences.

\section{Theme 5: Career assessment and technology}

Research in this category was proportionally also a core focus area for academia $(n=25 ; f=22.7 \%)$. Core themes included: the validity and structural equivalence of psychological measures in the South African context (e.g. Career Orientations Inventory), reliability of the Career Decision Profile, development of a new career interest questionnaire and the Career Development Questionnaire, validity of the Career Resilience Questionnaire, determining selection criteria, construct validity of the Career Myth Scale, constructing personality profiles, and computerised career counselling.

\section{Theme 6: Organisational career interventions}

Research on themes in this category proportionally represented only $5.4 \%(n=6)$. Core themes included: career guidance system, addressing barriers to career advancement,

TABLE 2: Frequencies of the dominant career research themes in organisations from 1970 to 2011.

\begin{tabular}{|c|c|c|c|}
\hline Research themes & Examples of dominant research themes & $n$ & $\%$ \\
\hline Theme 1: Issues of professional importance & $\begin{array}{l}\text { Career counselling, career planning practices, career guidance system, profile of industrial } \\
\text { psychologist }\end{array}$ & 8 & 7.3 \\
\hline Theme 2: Career theory and concepts & $\begin{array}{l}\text { Career theories, career identity, career salience, career resilience, career patterns, career } \\
\text { anchors and orientations, career attitudes, career choice, career success, career aspirations, } \\
\text { career advancement, psychological career resources, vocational interest, personality traits }\end{array}$ & 30 & 27.3 \\
\hline Theme 3: Developmental life stage studies & $\begin{array}{l}\text { Life stage perspectives, career development, career decision and indecision, career maturity, } \\
\text { early career, career expectations, barriers to career advancement }\end{array}$ & 12 & 10.9 \\
\hline Theme 4: World of work & $\begin{array}{l}\text { Developing women's potential, working women, graduate women's job expectations, } \\
\text { psychological contract, job satisfaction, career and life balance, work and family conflict, } \\
\text { retention, work readiness, protean career, boundaryless career, work and family interface and } \\
\text { spillover and enrichment, internal career, work-related concerns of HIV and AIDS, burnout, } \\
\text { retention factors, job embeddedness, career mobility, work engagement, subjective work } \\
\text { experiences }\end{array}$ & 29 & 26.4 \\
\hline Theme 5: Career assessment and technology & $\begin{array}{l}\text { Validity and structural equivalence of psychological measures in the SA context (e.g. } \\
\text { Career Orientations Inventory), reliability of Career Decision Profile, development of a new } \\
\text { interest questionnaire, Career Development Questionnaire, Career Resilience Questionnaire } \\
\text { validity, determining selection criteria, Construct validity of Career Myth Scale, constructing } \\
\text { personality profiles, computerised career counselling }\end{array}$ & 25 & 22.7 \\
\hline Theme 6: Organisational career interventions & $\begin{array}{l}\text { Career guidance system, addressing barriers to career advancement, anxiety management, } \\
\text { training in career planning and management, managing reality shock, mentoring }\end{array}$ & 6 & 5.4 \\
\hline Total & & 110 & 100 \\
\hline
\end{tabular}

$n$, used as means of number.

$N=110$. 
anxiety management, training in career planning and management, managing reality shock, and mentoring.

\section{Discussion}

This research critically reviewed dominant research trends from 1970 to 2011 in the careers field in the South African context, and evaluated these trends in terms of global and present national challenges that require empirical investigation in the contemporary South African world of work context. Overall, the findings indicate the lack of an evolving general trend of research focus areas in organisational career psychology over the years.

Proportionally, much of the research addressed issues pertaining to career theory and concepts and the world of work in the South African context. Similar to international trends (Creager, 2011), research on career concepts focused mostly on dynamics in the work setting, on concepts of job and career satisfaction and success, retention and career well-being issues (burnout, work engagement, subjective well-being), as well as on issues pertaining to the work and family interface. This trend seems to reflect the influence of the globally changing nature of work and careers on South African workplaces. However, considering that the changing nature of work and careers in a multi-cultural and multigenerational South African work context has, for many people, made some motivational and career development theories less relevant, more seems to be needed in the field of career theory research (Bergh, 2009). Chaichanasakul et al. (2011) also express a concern that the number of career theories from multicultural, cross-cultural, and international perspectives is extremely limited in the career research literature.

Although career assessment and technology proportionally also appear to have been amongst the dominant research focus areas, when evaluating the core themes and instruments discussed, more research seems to be needed in this area. Internationally, the career assessment field appears to continue to have a paucity of research on subjective assessments that can further career choice and development (Chaichanasakul et al., 2011; Creager, 2011; Hartung, 2010). Bergh (2009) posits that, in the post-apartheid South African multi-cultural workplace context, culture-free career assessment tests should be designed and tested, or refined and standardised. Creager (2011) also advocates the need for international research on culturally sensitive approaches to career counselling and assessment.

Research on developmental life stage issues, organisational career interventions and professional practice seem to be proportionally under-researched in the South African context. In the light of the present employment and employability challenges faced by South African youth in the emerging adulthood phase (DHET, 2010), more research needs to be undertaken in this area.
The question can be asked, how relevant and needs-driven was the reported research within the South African context? Numerous South African scholars (Augustyn \& Cillié, 2008; Katzell \& Austin, 1992; Moalusi, 2001; Pietersen, 2005; Schreuder, 2001; Sweder \& Fiske, 1986; Van Vuuren, 2006; Veldsman, 2001) have questioned the extent to which research in industrial and organisational psychology, in general, has been problem-orientated over the years. The same would probably apply to career psychology as a subfield of industrial and organisational psychology. Researchers in industrial and organisational psychology have been told that their research output often appears to be a function of data availability, without taking into account the actual needs of industry. Judging from the variety of topics studied in organisational career psychology over four decades, researchers can probably be accused of the same. Career anchors have, for example, been widely researched over the years, but since Schein (1977) established this concept over 30 years ago, no longitudinal research has been undertaken, which could have shed more light on the value of the concept in the contemporary world of work.

Moreover, in line with international concerns raised by Creager (2011) and Chaichanasakul et al. (2011), multicultural aspects of career assessment and development appear to need innovation and renewal in the South African work context. It is recommended that academia properly investigate the needs of a post-apartheid South African industry, to ensure that their research focus areas are relevant and that their research methods are linked to the nature of the identified problems and challenges. Important issues have received very little attention from researchers, such as the following:

- the new emerging psychological contract

- retention of talented and scarce-skills employees

- preparing young people for the world of work

- youth unemployment

- graduate employability and coping with employment instability

- work-family enrichment

- spillover and balance

- new career development and counselling models for the post-apartheid period

- multiculturalism

- information technology-driven knowledge society

- generational and socio-demographical differences

- the career prospects of women and employees with disabilities within the context of employment equity.

\section{Conclusion}

In the light of the findings of this study it can be concluded that organisational career psychology research in South Africa seems to be lagging behind in terms of international trends in career psychology research focus areas. Moreover, organisational career research in South Africa appears to need revival and innovation in terms of addressing the needs and concerns posed by the global world of work and postapartheid, multicultural South African workplaces. 
By the mid-1900s, Hall and Mirvis (1995) had already stated that the study of careers needed to become better connected to the career environment and become more multidisciplinary. Previous research on careers does not necessarily fit today's turbulent working environment. 'Hence, the nature of the research will have to match the nature of its subject: rapidly changing, fast learning and complex' (Hall \& Mirvis, 1995, p. 349). Moreover, being an applied discipline contributing to the psychology of working and living in a global posttraditional (new millennium) society, career research should bring innovative, relevant solutions that can be applied to the benefit of the career development issues that humans grapple with in their daily lives (Krieshok et al., 2011; Savickas, 2011). Longitudinal, multi-year, career-related studies addressing the development of people across their lifespan are required (Creager, 2011).

In the light of the challenges posed by global and national career-related needs and concerns, it appears that more research is needed in the following research focus areas of organisational career psychology:

- Transformation from jobs to jobless work. Employees are facing a number of employment transitions during their working lives. The digital revolution is changing the form of work and, therefore, demands that new questions should be asked by researchers. Long-term careers will still exist, but part-time and temporary work are increasing, wherein permanent jobs are being replaced by temporary assignments (Savickas, 2011). Career research should help determine the readiness of employees to adapt to the requirements of the evolving information society and what they need to successfully construct their careers in a boundary-less and jobless occupational world.

- Due to the reality of jobless work (and temporary assignments), the focus is now on employability rather than employment. Employability requires specific skills from people, in which the employability of employees and students is to be determined. The focus should not be for an individual to maintain employment but to remain employable and to manage his or her career through adaptability, intentionality, life-long learning and autobiographical reasoning (Savickas, 2011).

- Developing new career counselling models and theories relevant to the contemporary, multi-cultural working environment.

- People work for longer. In the future there will be more people working beyond the normal retirement age of 65 years. This could be by choice or necessity. It is becoming more difficult for people to retire for financial reasons. An area of research could be to determine whether or not an individual's interests change beyond retirement, and the results could help senior people choose appropriate new careers in the later stages of their lives (Chope, 2011).

- The career interests of emerging adults, especially those with disabilities, need to be investigated. Research has shown that people with disabilities rarely experience an optimal person-job fit as they are often misplaced, with no consideration of their interests and personality profiles in relation to the job profile (Turner, Unkefer, Chichy, Peper \& Juang, 2011).

- Taking the demands of the changing and existing working environment into account, predictors for career success remain an important research focus area.

- Research focusing on working women has increased. Areas that probably need more attention are the unique barriers to the career progression of women and the factors predicting their career success (Johnson \& Eby, 2011).

- More South African research is needed on the workfamily interface. Concepts such as work to family positive spill over and work to family enrichment need to be further investigated. Much that has been written on work-family conflict has a negative connotation, whilst the one domain (work or family) can also benefit from the positives of the other domain (Masuda, McNall, Allen \& Nicklin, 2012). The research should preferably be culture-related and more South African data are required.

- Research to determine the relationship between dispositional variables and work family conflict can be considered. Research has provided insights into the dispositional variables that serve as risk factors, as well as those that appear to serve a protective purpose against work-family conflict (Allen et al., 2012).

- Millions of people in South Africa are out of work. What can career psychologists do to improve the lives of the unemployed and underemployed? Current career research seems mostly to focus on the middle class in the corporate world.

\section{Limitations and recommendations for future research}

The limitations of the present study should be interpreted in the light of the stated objective of the study. It should be pointed out that the present study was approached from an academic perspective and did not include unpublished research. Using the SABINET portal to access documented, published peer-reviewed research articles, from only six accredited South African journals, necessarily excluded other research-related national and international publications and unpublished research. Only two researchers were involved in the primary data analysis. Trustworthiness of the findings could have been maximised by involving additional independent researchers in the data analyses. Although it is recognised that reporting the findings of the present research was considerably limited by the journal requirements and the nature of the research study, the findings could have been strengthened by quoting specific references and research, as examples of the six research themes.

Notwithstanding these limitations, the findings provide valuable preliminary insights that add to the body of knowledge that focuses on the evolution of the field of organisational career psychology in South Africa. The insights derived from the findings can be employed by academia and researchers in the field to plan future research initiatives that will contribute to the profession and practice of career guidance and counselling in the post-apartheid 
multi-cultural, multi-generational South African workplace. Such research directions should take cognisance of the challenge for career psychology research to remain relevant to the issues and concerns posed by the 21st century world of work.

\section{Acknowledgements Competing interests}

The authors declare that they have no financial or personal relationship(s) which may have inappropriately influenced them in writing this paper.

\section{Authors' contributions}

D.S. (University of South Africa) was the project leader and conducted the literature research and data analyses and assisted in writing up the report. M.C. (University of South Africa) assisted with the literature research, the data analyses and writing up the report.

\section{References}

Allen, T.D., Johnson, R.C., Saboe, K.N., Cho, E., Dumani, S., \& Evans, S. (2012) Dispositional variables and work-family conflict: A meta-analysis. Journal of Vocational Behavior, 80(1), 17-26. http://dx.doi.org/10.1016/j.jvb.2011.04.004

Arnett, J.J. (2000). Emerging adulthood: A theory of development from the late teen through the twenties. American Psychologist, 55(5), 469-480. http://dx.doi. org/10.1037/0003-066X.55.5.469, PMid:10842426

Augustyn, J.C.D., \& Cillié, G.C. (2008). Theory and practice in industrial psychology: Quo Vadis? SA Journal of Industrial Psychology/SA Tydskrif vir Bedryfsielkunde, Quo Vadis? SA Journal of Industrial Psychology/SA Tydskr
34(1), 70-75. http://dx.doi.org/10.4102/sajip.v34i1.419

Arthur, M.B., Inkson, K., \& Pringle, J.K. (1999). The new careers: Individual action and economic change. Thousand Oaks, CA: Sage.

Bailyn, L. (1977). Involvement and accommodation in technical careers: An inquiry into the relation to work at mid-career. In J. van Maanen (Ed.), Organizational careers: Some new perspectives, (pp. 109-132). New York: Wiley.

Bailyn, L. (1980). The slow-burn way to the top: Some thoughts on the early years of organizational career. In C.B. Derr (Ed.), Work, family and the career, (pp. 94-105). New York: Praeger.

Bergh, Z.C. (2009). Fields of study and practice areas in industrial and organisational psychology. In Z.C. Bergh \& A.L. Theron (Eds.), Psychology in the work context, (pp. 16-29). Cape Town: Oxford University Press.

Brown, C., George-Curran, R., \& Smith, M.L. (2003). The role of emotional intelligence in the career commitment and decision-making process. Journal of Caree Assessment, 11(4), 379-392. http://dx.doi.org/10.1177/1069072703255834

Chaichanasakul, A., He, Y., Chen, H.H., Allen, G.E.K., Khairallah, T.S., \& Ramos, K. (2011). Journal of Career Development: A 36-year content analysis (1972-2007). Journal of Career Development, 38(6), 440-455. http://dx.doi. org/10.1177/0894845310380223

Chope, R.C. (2011). Reconsidering interests: The next big idea in career counseling theory research and practice. Journal of Career Assessment, 19(3), 343-352. http://dx.doi.org/10.1177/1069072710395540

Coetzee, M. (2011). The psychology of personnel retention. In M. Coetzee \& D. Schreuder (Eds.), Personnel Psychology, (pp. 233-271). Cape Town: Oxford University Press.

Conger, J.A. \& Fulmer, R.M. (2003). Developing your leadership pipeline. Harvard Business Review, 81(12), 76-85.

Cotter, E.W., \& Fouad, N.A. (2011). The relationship between subjective well-being and vocational personality type. Journal of Career Assessment, 19(1), 51-60. http://dx.doi.org/10.1177/1069072710382614

Creager, M.F.S. (2011). Practice and research in career counseling and development - 2010. The Career Development Quarterly, 59, 482-527. http://dx.doi. org/10.1002/j.2161-0045.2011.tb00973.x

Crocetti, E., Palmonari, A., \& Pojaghi, B. (2011). Work identity, wellbeing and time-perspective of typical and atypical young workers. In M. Cortini, G. Tanucci \& E. Morin (Eds.), Boundaryless careers and occupational well-being, (pp. 181-190). New York: Palgrave McMillan.

Department of Higher Education and Training (DHET). (2010). Framework for the National Skills Development Strategy 2011/12-2015/16. Pretoria: DHET.
Derr, C.B., \& Briscoe, J.P. (2007). The catalytic 1970s: Lessons for the 2000s. In H. Gunz \& M. Peiperl (Eds.), Handbook of career studies, (pp. 528-541). London: Sage. http://dx.doi.org/10.4135/9781412976107.n29

Derr, C.B., Briscoe, J.P., \& Buckner, K. (2002). Managing leadership in the United States. In C.B. Derr, S. Roussillon \& F. Bournois (Eds.), Cross-cultural approaches to leadership development. Westport, CT: Quorum Books.

Driver, M.J. (1980). Career concepts and organizational change. In C.B. Derr (Ed.), Work, family and the career, (pp. 18-37). New York: Praeger.

Esterberg, K.G. (2002). Qualitative methods in social research. New York: McGraw-Hill.

Feldman, D., \& Ng, T. (2007). Careers: Mobility, embeddedness, and success. Journal of Management, 33(3), 350-377. http://dx.doi.org/10.1177/0149206307300815

Fugate, M., Kinicki, A.J., \& Ashforth, B.E. (2004). Employability: A psycho-social construct, its dimensions, and applications. Journal of Vocational Behaviour, 65, 14-38. http://dx.doi.org/10.1016/j.jvb.2003.10.005

Greenhaus, J.H., \& Powell, G.N. (2006). When work and family are allies: A theory of work-family enrichment. Academy of Management Review, 31, 72-92. http:// dx.doi.org/10.5465/AMR.2006.19379625

Gunz, H., \& Peiperl, M. (2007). Handbook of career studies. London: Sage.

Hall, D.T. (1976). Careers in organizations. CA: Goodyear.

Hall, D.T., \& Mirvis, P.H. (1995). Careers as lifelong learning. In A. Howard (Ed.), The changing nature of work, (pp. 323-361). San Francisco: Jossey-Bass.

Hartung, P.J. (2010). Practices and research in career counseling and development - 2009. The Career Development Quarterly, 59, 98-142. http://dx.doi. org/10.1002/j.2161-0045.2010.tb00057.x

Hartung, P.J. (2011). Barrier or benefit? Emotion in life-design. Journal of Career Assessment, 19(3), 296-305. http://dx.doi.org/10.1177/1069072710395536

Johnson, C.D., \& Eby, L.T. (2011). Evaluating career success of African American males: It's what you know and who you are that matters. Journal of Vocational Behavior, 79, 699-709. http://dx.doi.org/10.1016/j.jvb.2011.03.021

Katzell, R.A., \& Austin, J.T. (1992). From then to now: The development of industrialorganisational psychology in the United States. Journal of Applied Psychology, 77(6), 803-835. http://dx.doi.org/10.1037/0021-9010.77.6.803

Kidd, J.M. (2008). Exploring components of career well-being and the emotions associated with significant career experiences. Journal of Career Development 35(2), 166-186. http://dx.doi.org/10.1177/0894845308325647

Krieshok, T.S., Motl, T.C., \& Rutt, B.T. (2011). The evolution of vocational psychology: Questions for a postmodern applied discipline. Journal of Career Assessment 19(3), 228-239. http://dx.doi.org/10.1177/1069072710395530

Levinson, D.J. (1978). The seasons of a man's life. New York: Ballantine.

Levinson, D.J. (1986). A conception of adult development. American Psychologist, 41 3-13. http://dx.doi.org/10.1037/0003-066X.41.1.3

Masuda, A.D., McNall, L.A., Allen, T.D., \& Nicklin, J.M. (2012). Examining the constructs of work to family enrichment and positive spillover. Journal of Vocational Behavior, 80(1), 197-210. http://dx.doi.org/10.1016/j.jvb.2011.06.002

Moalusi, K.P. (2001). Repositioning industrial psychology for the creation of new futures in turbulent times. SA Journal of Industrial Psychology/SA Tydskrif vir Bedryfsielkunde, 27(4), 17-21.

Ng, T.W.H., Sorensen, K.L., Eby, L.T., \& Feldman, D.C. (2007). Determinants of job mobility: A theoretical integration and extension. Journal of Occupational and Organizational Pyschology, 80, 363-386. http://dx.doi. org/10.1348/096317906X130582

Obschonka, M., Silbereisen, R.K., \& Wasilewski, J. (2012). Constellations of new demands concerning careers and jobs: Results from a two-country study on social and economic change. Journal of Vocational Behavior, 80, 211-223. http://dx.doi. org/10.1016/j.jvb.2011.08.002

Petticrew, M., \& Roberts, H. (2006). Systematic reviews in the social sciences: A practical guide. Oxford: Blackwell. http://dx.doi.org/10.1002/9780470754887

Pietersen, H.J. (2005). Knowledge development in industrial/organisational psychology (South Africa). SA Journal of Industrial Psychology/SA Tydskrif vir Bedryfsielkunde, 31(2), 78-85.

Savickas, M.L. (2005). The theory and practice of career construction. In S.D. Brown \& R.W. Lent (Eds.), Career development and counselling: Putting theory and research to work, (pp. 42-70). Hoboken, NJ: John Wiley \& Sons.

Savickas, M.L., Nota, L., Rossier, J., Dauwalder, J.P., Duarte, M.E., \& Guichard, J. (2009) Life designing: A paradigm for career construction in the 21 st century. Journal of Vocational Behavior, 75, 239-250. http://dx.doi.org/10.1016/j.jvb.2009.04.004

Savickas, M.L. (2011). New questions for vocational psychology: Premises, paradigms, and practices. Journal of Career Assessment, 19(3), 251-258. http://dx.doi. org $/ 10.1177 / 1069072710395532$

Schein, E.H. (1977). Career anchors and career paths: A panel study of management school graduates. In J. van Maanen (Ed.), Organizational careers: Some new perspectives, (pp. 49-64). New York: Wiley. 
Schein, E.H. (1996). Career anchors revisited. Implications for career development in the 21st century. Academy of Management Executive, 1, 80-88.

Schein, E.H. (2006). Career anchors. In J.H. Greenhaus \& G.A. Callanan (Eds.) Encyclopedia of career development, (pp. 63-69). New Dehli: Sage Publication.

Schein, E.H. (2007). Career research: Some issues and dilemmas. In H. Gunz \& M. Peiperl (Eds.), Handbook of career studies, (pp. 573-576). London: Sage.

Schreuder, A.M.G. (2001). The development of industrial psychology at South African universities: A historical overview and future perspective. SA Journal of Industrial Psychology/SA Tydskrif vir Bedryfsielkunde, 27(4), 2-7.

Schreuder, A.M.G., \& Coetzee, M. (2010). An overview of industrial and organisationa psychology research in South Africa: A preliminary study. SA Journal of Industrial Psychology/SA Tydskrif vir Bedryfsielkunde, 36(1), Art. \#903, 11 pages. http:// dx.doi.org/10.4102/sajip.v36i1.903

Schreuder, AMG., \& Coetzee, M. (2011). Careers: An organisational perspective. (4th edn). Cape Town: Juta.
Super, D.E. (1990). A life-span, life-space approach to career development. In D. Brown, L. Brooks \& Associates (Eds.), Career choice and development: Applying contemporarytheoriesto practice, (pp.30-45)(2ndedn). San Francisco: Jossey-Bass.
cont: Applying

Sweder, R.A., \& Fiske, D.W. (1986). Uneasy social science. In D.W. Fiske \& R.A. Sweder (Eds.), Metatheory in social science: Pluralism and subjectivities, (pp. 15-25). Chicago: University of Chicago Press.

Turner, S., Unkefer, L.G., Cichy, B.E., Peper, C., \& Juang, J. (2011). Career interests and self-estimated abilities of young aduls with disabilities. Journal of Career Assessment, 19(2) 183-196. http://dx.doi.org/10.1177/1069072710385651

Van der Heijde, C.M., \& Van der Heijden, B.I.J.M. (2006). A competence-based and multidimensional operationalisation of employability. Human Resource Management, 45(3), 449-476. http://dx.doi.org/10.1002/hrm.20119

Van Vuuren, L. (2006). Industrial psychology: Goodness of fit? Fit for goodness. Inaugural lecture, University of Johannesburg, Johannesburg.

Veldsman, T. (2001). A new playing field, game and/or different rules? Into the future with industrial psychology as a discipline and profession. SA Journal of Industrial Psychology/SA Tydskrif vir Bedryfsielkunde, 27(4), 34-41. 